\title{
Penerapan Perjanjian Internasional di Pengadilan Nasional Indonesia: Studi terhadap Putusan-Putusan Mahkamah Konstitusi*
}

\author{
Kama Sukarno**
}

\begin{abstract}
Abstrak
Putusan-putusan MK belum secara tegas memperlihatkan kedudukan dan fungsi perjanjian internasional sebagai salah satu sumber hukum di Indonesia. Hal ini dapat dilihat dari inkonsistensi yurisprudensi MK dalam menerapkan perjanjian internasional. Di lain pihak, diterapkannya perjanjian internasional oleh MK secara inkonsisten dapat berujung pada pelanggaran hukum internasional oleh Indonesia. Penelitian ini bertujuan untuk menjelaskan mengenai penerapan perjanjian internasional selama ini di MK, serta mengkaji dan merumuskan bagaimana sebaiknya perjanjian internasional diterapkan di pengadilan nasional pada masa yang akan datang. Untuk menunjang penelitian ini, dilakukan wawancara kepada ahli hukum internasional, ahli hukum tata negara, dan praktisi hukum. Terdapat dua hal yang diperoleh dari penelitian ini. Pertama, diamnya UUD 1945 dalam menjelaskan fungsi perjanjian internasional dalam sistem hukum nasional menjadi faktor utama yang melatarbelakangi inkonsistensi yurisprudensi MK. Kedua, MK inkonsisten dalam menerapkan perjanjian internasional sebagai sumber hukum materiil namun juga sebagai sumber hukum formil. Disarankan agar MK dapat memberikan penafsiran konstruktif pada Pasal 11 UUD 1945 serta menempatkan perjanjian internasional sebagai satu sumber hukum yang berdiri sendiri, sehingga tidak dapat diuji materi yang dapat berakibat pada terlanggarnya kewajiban internasional dari Negara Indonesia.
\end{abstract}

Kata kunci: hukum internasional, mahkamah konstitusi, perjanjian internasional, sumber hukum, UUD 1945.

\section{The Application of Treaties in the Indonesian National Courts: Study on the Constitutional Court Decisions}

\begin{abstract}
The Constitutional Court's Decisions have not clearly showed the position and the function of treaties as one of the legal sources in Indonesia. This is clearly seen from the inconsistency of treaties application by Constitutional Court.. The purpose of this study is to review the application of treaties by Constitutional Court to date, and to formulate how it should be done on the implementation of international Treaties on national court in the future. To support this research, interview with experts has been done. Two things obtained through this research. First, the UUD 1945 's silence related to the function of treaties in the domestic law was the main factor behind the inconsistencies of the Constitutional Court decisions. Second, the Constitutional Court to date was mixing the function of treaties both as a

PADJADJARAN Jurnal IImu Hukum Volume 3 Nomor 3 Tahun 2016 [ISSN 2460-1543] [e-ISSN 2442-9325]

* Jurnal ini merupakan adaptasi dari tugas akhir (skripsi) penulis. Adapun tugas akhir tersebut dikerjakan dengan bimbingan oleh Atip Latipulhayat S.H., LL.M., Ph.D dan Susi Dwi Harijanti S.H., LL.M., Ph.D.

** Alumnus Fakultas Hukum Universitas Padjadjaran, Jl. Dipati Ukur No. 35 Bandung, kamasukarno@gmail.com, S.H. (Universitas Padjadjaran).
\end{abstract}


material source of law and as a formal source of law. This research suggested, the Constitutional Court must decide a constructive decision to clarify the ambiguous position of the international treaties in the future by interpreting Article 11 of UUD 1945, also to put treaties as a different kind of source of law that can't be reviewed by the Constitutional Court to avoid the violation of the international law.

Keywords: international law, constitutional court, treaty, source of law, the 1945 Constitution.

\section{A. Pendahuluan}

Hukum internasional setidaknya telah melewati 3 (tiga) fase, ${ }^{1}$ yang mana masingmasing fase memengaruhi evolusi hukum internasional. Fase pertama, hukum internasional berperan dalam mengatur hubungan negara dengan negara. ${ }^{2}$ Fase kedua adalah masa setelah Perang Dunia I, hukum internasional mulai menyentuh individu untuk melindungi dan memenuhi Hak Asasi Manusia (HAM). ${ }^{3}$ Fase ketiga ditandai oleh globalisasi dan demokratisasi negara-negara yang memunculkan kekuasaan Parlemen. Fase ketiga mengakibatkan hubungan hukum internasional dan hukum nasional menjadi semakin kompleks karena kehadiran hukum internasional dalam hukum nasional diuji dari segi democratic legitimacy. ${ }^{4}$

Hukum internasional itu sendiri bila dibedah berdasarkan sumbernya, terbagi atas empat instrumen, yakni perjanjian internasional, kebiasaan internasional, doktrin, dan putusan pengadilan. Sumber hukum internasional ini didapat dari Pasal 38 ayat (1) Statuta Mahkamah Internasional yang telah diakui sebagai suatu pernyataan authoritative sebagai sumber hukum internasional. ${ }^{5}$ Tentunya dalam

Wawancara dengan Damos Dumoli Agusman, 10 Februari 2016, melalui linimasa Facebook.

2 Fase pertama ini ditandai dengan munculnya Perjanjian Westphalia 1648 yang melahirkan negara-negara bangsa yang berdaulat di Eropa. Pada fase ini belum ada perkembangan dari doktrin konstitusionalisme dan pemisahan kekuasaan, sehingga konflik antara hukum internasional dan hukum nasional belum ditemukan. Lihat juga Damos Dumoli Agusman, Treaties under Indonesian Law: A Comparative Study, Bandung: PT. Remaja Rosdakarya, 2014, hlm. 54.

3 Meningkatnya dorongan untuk jaminan akan HAM yang ditandai dengan lahirnya DUHAM yang menjadi ladasan filosofis dari PBB serta konvensi-konvensi HAM di kemudian hari. Lihat Humphrey JP, "The Universal Declaration of Human Rights: Its History, Impact and Judical Character", dalam buku Human Rights: Thirty Years After the Universal Declaration, yang disusun oleh Ramcharan B.G. (eds), Netherlands: Springer, 1979, hlm. 37. Di saat yang sama terjadi perkembangan doktrin tentang konstitusi-konstitusi modern yang mana di dalam terikat konsep kedaulatan dan separation of powers. Konflik antara hukum internasional dan hukum nasional mulai nyata terlihat pada fase ini. Lihat Damos Dumoli Agusman, Treaties Under Indonesian Law: A Comparative Study, Loc. cit.

$4 \quad$ Pada fase ketiga yakni dimulai sejak akhir abad ke-20, hukum internasional tidak lagi semata-mata menyentuh kehidupan manusia dibidang HAM saja. Berkembangnya globalisasi memunculkan kebutuhan-kebutuhan hukum internasional mengatur masalah ekonomi, kebudayaan, dan lingkungan. Kebutuhan-kebutuhan yang muncul akibat globalisasi mulai melunturkan konsep kedaulatan yang sebelumnya kaku. Lihat: David Haljan, Separating Powers: International Law before National Courts, Leuven:T.M.C Asser Press, 2013, hlm.1.

$5 \quad$ Ibid, hlm. 70. 
konteks perkembangan hukum internasional, sumber-sumber hukum internasional secara otomatis ikut berkembang.

Terkait perkembangan dari perjanjian internasional sebagai salah satu sumber hukum internasional, perjanjian internasional telah sangat berkembang dari segi kuantitas maupun kualitas. Berdasarkan situs resmi PBB, semenjak PBB didirikan terdapat 32 perjanjian internasional yang ditetapkan oleh PBB dan hanya 7 dari 32 perjanjian internasional tersebut yang dibuat sebelum tahun $1970 .^{6}$ Perkembangan internasional ini memiliki tantangan tersendiri bagi pemerintahan negaranegara. Meningkatnya praktik democratic legitimacy pada Parlemen, di mana kebijakan-kebijakan eksekutif membutuhkan otorisasi lebih oleh Parlemen, menjadi hambatan tersendiri bagi negara yang belum memiliki sistem hukum nasional yang mengatur perjanjian internasional dengan konsisten. Perkembangan democratic legitimacy di Indonesia dapat dilihat pada perubahan Undang-Undang Dasar Negara Republik Indonesia Tahun 1945 (UUD 1945) pasca Reformasi 1998, yang mana terjadi pergeseran kekuasaan dari executive heavy menjadi legislative heavy pada sistem pemerintahan Indonesia. ${ }^{7}$ Dari sisi perspektif hukum internasional, hal ini dapat menghambat diterapkannya perjanjian internasional yang telah mengikat negara-negara. Berdasarkan hal ini pula permasalahan terkait hubungan hukum internasional dengan hukum nasional menjadi semakin nyata. ${ }^{8}$

Masalah praktik muncul di ranah Pengadilan Nasional Indonesia ketika Hakim merujuk pada perjanjian internasional, yang dalam penelitian ini adalah Mahkamah Konstitusi (MK). Dalam memutus perkara yang diajukan kepadanya, MK menggunakan sumber hukum sebagai alat untuk memeriksa perkara. Berdasarkan praktik Mahkamah Konstitusi selama ini, hakim beberapa kali merujuk pada perjanjian internasional dalam memutus perkara dengan asas rechtsviding sebagai landasan. Namun, belum ada satu konsistensi akan penerapan perjanjian internasional di pengadilan dikarenakan belum adanya aturan yang jelas dan kebiasaan yang konsisten. Dalam sebagian putusan, MK memang sudah merujuk kepada perjanjian internasional yang signed and ratified; sebagian putusanputusan pengadilan merujuk pada perjanjian internasional yang signed but not yet ratified; terdapat putusan-putusan yang merujuk pada Perjanjian International yang mana Indonesia sama sekali tidak menjadi State-Party; bahkan terdapat suatu Putusan MK yang merujuk sekaligus pada perjanjian-perjanjian internasional yang

6 United Nations, “United Nations Treaty Collections”, https://treaties.un.org/doc/source/events/2005/list.pdf, diakses pada 29 Maret 2016.

Bagir Manan, Membedah UUD 1945, Malang: Universitas Brawijaya Press, 2012, hlm. 123.

8 Teori dualisme (berdasarkan pandangan voluntarisme) memisahkan hukum internasional-hukum nasional dan teori monisme (berdasarkan pandangan objektivis) menganggap hukum internasional-hukum nasional berada dalam satu perangkat. Lihat: Mochtar Kusumaatmadja, Pengantar Hukum Internasional, Bandung: PT. Alumni, 2003, hlm. 56. 
signed and ratified, signed but not yet ratified. Jikapun hakim merujuk pada perjanjian internasional yang signed and ratified, penerapan tersebut belum memiliki dasar atau kaidah yang jelas. Beberapa contoh putusan-putusan tersebut adalah sebagai berikut:

1. Beberapa putusan MK yang menggunakan International Covenant on Civil and Political Rights (ICCPR) 1966 (Indonesia menandatangani ICCPR pada 23 Februari 2006 dan diratifikasi 23 Mei 2006), antara lain:

a. Pengujian Materi Undang-Undang Nomor 26 Tahun 2000 tentang Pengadilan Hak Asasi Manusia (UU Pengadilan HAM); ${ }^{9}$

b. Pengujian Materi Kitab Undang-Undang Hukum Pidana (KUHP) tentang Penghinaan Kepada Presiden dan Wakil Presiden Republik Indonesia; ${ }^{10}$ dan

c. Pengujian Materi Undang-Undang Nomor 11 Tahun 2008 tentang Informasi dan Transaksi Elektronik. ${ }^{11}$

2. Dalam Putusan MK pada Pengujian Materi tentang Undang-Undang Nomor 22 Tahun 1997 Narkotika (UU Narkotika), ${ }^{12}$ MK menafsirkan kejahatan narkotika yang terdapat dalam UU Narkotika sebagai bagian dari the most serious crime yang digolongkan pada Pasal 6 ICCPR. MK menyatakan bahwa penafsiran tersebut merukapakan metode penafsiran sistematis dengan VCLT 1969 sebagai jembatan. VCLT sendiri tidak pernah diratifikasi Indonesia, meskipun sudah diterima negara-negara di dunia sebagai bagian dari hukum kebiasaan internasional.

3. Putusan MK tahun 2003 tentang permohonan pengujian Undang-Undang Nomor 16 Tahun 2003 tentang Penetapan Peraturan Pemerintah pengganti Undang-Undang Nomor 2 Tahun 2002 tentang Pemberlakuan Peraturan Pemerintah Pengganti Undang-Undang Nomor 1 Tahun 2002 tentang Pemberantasan Tindak Pidana Terorisme (UU Terorisme), pada Peristiwa Peledakan Bom di Bali tanggal 12 Oktober 2002, menjadi Undang-Undang; putusan ini merujuk kepada ICCPR (pada saat itu Indonesia belum menjadi state-party), ICC 1998 (Indonesia bukan state-party sampai saat tulisan ini dibuat), dan beberapa konvensi regional Amerika (yang mana tidak mungkin Indonesia menjadi party dari konvensi regional Amerika karena Indonesia

9 Putusan Mahkamah Konstitusi Nomor 065/PUU-II/2004, putusan diucapkan dalam sidang Pleno Mahkamah Konstitusi yang terbuka untuk umum pada hari Kamis, 3 Maret 2005.

10 Putusan Mahkamah Konstitusi Nomor 013-022/PUU-IV/2006, putusan diucapkan dalam sidang Pleno Mahkamah Konstitusi yang terbuka untuk umum pada hari Rabu, 6 Desember 2006.

11 Putusan Mahkamah Konstitusi Nomor 5/PUU-VIII/2010, putusan diucapkan dalam sidang Pleno Mahkamah Konstitusi yang terbuka untuk umum pada hari Kamis, 24 Februari 2011.

12 Putusan Mahkamah Konstitusi Nomor 2-3/PUU-V/2007, putusan diucapkan dalam sidang Pleno Mahkamah Konstitusi yang terbuka untuk umum pada hari Selasa, 30 Oktober 2007. 
berada di Asia). ${ }^{13}$ Analisa penelitian ini nantinya juga akan menunjukan apakah dalam putusan ini, MK merujuk pada perjanjian-perjanjian internasional tersebut sebagai norma dari hukum kebiasaan internasional, norma yang ada pada prinsip-prinsip hukum umum, atau memang diambil sebagai norma dari sebuah perjanjian internasional yang berdiri sendiri.

4. Mahkamah Konstitusi dalam memutus perkara permohonan Pengujian

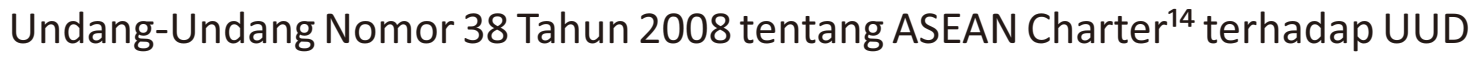
1945, dalam putusannya Mahkamah menolak seluruh permohonan pemohon. Namun, menyatakan bahwa Mahkamah berwenang mengadili permohonan pemohon, artinya berwenang mengadili undang-undang (UU) yang bersubstansi hukum internasional.

5. Mahkamah Konstitusi dalam memutus perkara permohonan Pengujian Undang-Undang Nomor 1/PNPS/1965 tentang Pencegahan Penyalahgunaan dan/atau Penodaan Agama terhadap UUD 1945, dalam putusannya menyatakan bahwa "Penghormatan negara Indonesia atas berbagai konvensi serta perangkat hukum Internasional termasuk HAM haruslah tetap berdasarkan pada falsafah dan konstitusi Negara Kesatuan Republik Indonesia". 15

6. Putusan Mahkamah Konstitusi Indonesia terkait Permohonan Judicial Review Undang-Undang Nomor 3 Tahun 1997 tentang Pengadilan Anak (UU Pengadilan Anak), dalam pertimbangannya menyatakan bahwa perjanjian-perjanjian internasional tentang Hak Anak memang dapat digunakan MK sebagai alat perbandingan, namun dalam hal ini perjanjian-perjanjian internasional itu tidak dapat menentukan batas umur anak secara konstitusional. ${ }^{16}$

Inkonsistensi dari Mahkamah Konstitusi selama ini membawa ketidakpastian hukum kepada masyarakat Indonesia, bahkan kepada masyarakat Internasional. Terlebih lagi, berdasarkan Putusan MK pada Pengujian Undang-Undang Nomor 38 Tahun 2008 tentang ASEAN Charter, MK menyatakan berwenang menguji ASEAN Charter. Bilamana memang MK dapat menguji perjanjian internasional, tentu hal ini dapat menyebabkan Indonesia melanggar international obligations yang sudah melekat kepadanya. Oleh karena itu, setidaknya penelitian ini akan menjawab 2 identifikasi masalah, yakni pertama, mengenai fungsi dan kedudukan perjanjian internasional di Indonesia berdasarkan praktik Pengadilan Nasional Indonesia,

13 Putusan Mahkamah Konstitusi Nomor 13/PUU-I/2003, putusan diucapkan dalam sidang Pleno Mahkamah Konstitusi yang terbuka untuk umum pada hari Jumat, 23 Juli 2004.

14 Putusan Mahkamah Konstitusi Nomor 38/PUU-IX/2011, putusan diucapkan dalam sidang Pleno Mahkamah Konstitusi yang terbuka untuk umum pada hari Senin, 12 Maret 2012, hIm. 197

15 Putusan Mahkamah Konstitusi Nomor 140/PUU-VII/2009, putusan diucapkan dalam sidang Pleno Mahkamah Konstitusi yang terbuka untuk umum pada hari Senin, 19 April 2010, hlm. 275.

16 Putusan Mahkamah Konstitusi Nomor 1/PUU-VIII/2010, putusan diucapkan dalam sidang Pleno Mahkamah Konstitusi yang terbuka untuk umum pada hari Rabu, 2 Februari 2011, hlm. 151. 
khususnya Mahkamah Konstitusi, selama ini; dan kedua, mengenai bagaimana perihal penerapan perjanjian internasional diterapakan di Pengadilan Nasional Indonesia, khususnya Mahkamah Konstitusi, di masa depan.

\section{B. Fungsi dan Kedudukan Perjanjian Internasional di Indonesia Berdasarkan Putusan-Putusan Mahkamah Konstitusi}

MK memutus perkara-perkara yang berhubungan dengan perjanjian internasional dengan berbagai variasi. MK pernah merujuk langsung kepada perjanjianperjanjian internasional yang mana Indonesia bukan merupakan Negara-Peserta; merujuk kepada UU Ratifikasi dengan anggapan bahwa UU Ratifikasi tidak terlepaskan dari perjanjian internasional yang diratifikasi; MK merujuk kepada UU implementasi dari perjanjian internasional yang telah diratifikasi; menggunakan hukum kebiasaan internasional (VCLT 1969) untuk melakukan penafsiran sistematis antara 2 perjanjian internasional yang telah diratifikasi; bahkan terkadang MK merujuk kepada semua jenis varian yang disebutkan. Berdasarkan analisis terhadap putusan-putusan tersebut, setidaknya ditemukan beberapa poin, yaitu:

\section{Supremasi UUD 1945}

Hakim Konstitusi I Dewa Gede Palguna mengatakan bahwa di Indonesia berlaku supremasi UUD 1945, yang berarti bahwa UUD 1945 merupakan norma tertinggi yang tidak dapat dikalahkan oleh norma lain manapun. ${ }^{17}$ Berdasarkan 5 (lima) putusan yang dikaji dalam skripsi ini, tidak ada satupun putusan MK yang menunjukan bahwa MK menjadikan suatu norma yang mengalahkan UUD 1945.

Putusan MK Nomor 065/PUU-II/2004 tentang Jucidicial Review UU Pengadilan HAM (asas retroaktif), MK menyatakan dalam Pertimbangan Hukum bahwa pengesampingan asas non-retroaktif secara konstitusional ditegaskan oleh Pasal 28J Ayat (2) UUD 1945. Pada kasus tersebut, Para Pemohon mendalilkan bahwa terdapat norma-norma hukum internasional yang secara tegas melarang penerapan asas retroaktif. Dengan MK menjawab bahwa Pasasl 28J Ayat (2) UUD 1945 menyediakan ruang untuk pengesampingan asas non-retroaktif, secara implisit MK menyatakan bahwa norma-norma hukum internasional tidak berlaku selama UUD 1945 mengatakan lain. ${ }^{18}$

Putusan MK Nomor 012/PUU-1/2003 tentang Pengujian Undang-Undang Nomor 13 Tahun 2003 tentang Ketenagakerjaan, MK menyatakan bahwa standar dan norma yang dikenal dalam konvensi-konvensi ILO harus disesuaikan dengan

\footnotetext{
17 Wawancara dengan I Dewa Gede Palguna, 27 Juli 2016, bertempat di Kantor Mahkamah Konstitusi Republik Indonesia.

18 Dalam putusan ini MK juga menyatakan bahwa pengesampingan asas non-retroaktif dalam UUD 1945 juga sejalan dengan norma-norma hukum internasional lain yang didalilkan oleh pemohon.
} 
ukuran yang dikenal oleh UUD $1945 .{ }^{19}$ Kutipannya sebagai berikut:

"Seandainyapun hal itu benar bertentangan dengan standard ILO quod non- maka standard dan norma-norma yang demikian haruslah dilihat sebagai bagian dari standard dan norma yang berlaku di Indonesia melalui ukuran yang dikenal dalam UUD 1945. Hal itu disebabkan hak asasi tidak dipandang sebagai sesuatu yang berlaku mutlak. Pasal 28J ayat (2) UUD 1945 menetapkan bahwa dalam menjalankan hak dan kebebasannya, setiap orang wajib tunduk kepada pembatasan yang ditetapkan dengan undang-undang dengan maksud semata-mata untuk menjamin pengakuan serta penghormatan atas hak dan kebebasan orang lain dan untuk memenuhi tuntutan yang adil sesuai dengan pertimbangan moral, nilai-nilai agama, keamanan dan ketertiban umum dalam suatu masyarakat demokratis."

Putusan MK Nomor 1/PUU-VIII/2010 tentang Judicial Review UU Pengadilan Anak, MK menyatakan bahwa seluruh instrumen hukum internasional hanya dapat dijadikan sebagai bahan perbandingan dalam menentukan batas usia anak, namun instrumen hukum internasional tidak dapat dijadikan batu uji an sich dalam menilai konstitusionalitas batas usia anak. ${ }^{20}$

Pada Putusan MK Nomor 140/PUU-VII/2009 tentang Judicial Review UndangUndang Nomor 1/PNPS/1965 tentang Pencegahan dan Penyalahgunaan dan/atau Penodaan Agama, MK secara tegas menjelaskan supremasi UUD 1945 di atas perjanjian internasional. MK mengatakan, "Penghormatan Negara Indonesia atas berbagai perangkat hukum internasional termasuk HAM harus tetap berdasarkan falsafah dan konstitusi NKRI". ${ }^{21}$ Pada pertimbangan hukum tersebut juga MK menyatakan bahwa konsep dan prinsip Negara Hukum Indonesia tidak dapat disamakan begitu saja dengan prinsip negara hukum yang diangkat secara universal lewat instrumen-instrumen hukum internasional maupun prinsip negara hukum yang diangkat oleh ahli-ahli hukum tertentu.

Keempat Putusan MK di atas, yaitu Putusan MK Nomor 1/PUU-II/2004; Putusan MK Nomor 012/PUU-I/2003; Putusan MK Nomor 140/PUU-VII/2009; dan Putusan MK Nomor 1/PUU-VIII/2010; menggambarkan supremasi UUD 1945. Sedangkan pada 6 Putusan MK yang lain, meski tidak ada kalimat-kalimat eksplisit yang menyatakan supremasi UUD 1945 seperti Putusan MK Nomor 012/PUU-

\footnotetext{
19 Putusan Mahkamah Konstitusi Nomor 12/PUU-I/2003, putusan diucapkan dalam sidang Pleno Mahkamah Konstitusi yang terbuka untuk umum pada hari Kamis, 28 Oktober 2004, hlm. 113.

20 Putusan Mahkamah Konstitusi Nomor 1/PUU-VIII/2010, Op.cit., hlm. 151.

21 Poin [3.34.9 Putusan Mahkamah Konstitusi Nomor 140/PUU-VII/2009, Op.cit., hlm. 275.
} 
I/2003 dan Putusan MK Nomor 1/PUU-VIII/2010, tidak pula mengenyampingkan UUD 1945 di bawah instrumen hukum internasional yang dirujuk. Dapat disimpulkan, bahwa meski status instrumen hukum internasional dalam sistem hukum nasional belum jelas, namun dipastikan bahwa instrumen hukum internasional tidak sejajar maupun berada di atas UUD 1945 (huruf tebal oleh penulis).

Amerika Serikat mengenal prinsip supremacy clause dalam Konstitusi-nya. Pasal VI Paragraf 2 Konstitusi AS menyatakan bahwa Konstitusi Negara Federal AS, federal statutes, dan perjanjian internasional adalah 3 bentuk hukum yang suprematif, sehingga peraturan perundang-undangan lain tidak boleh bertentangan dengan ketiganya. UUD 1945 tidak menjelaskan secara eksplisit mengenai supremacy clause, dengan kata lain tidak menyebutkan posisi dan kedudukan hukum di bawah UUD 1945. Namun, berdasarkan praktik MK hingga hari ini, juga berdasarkan wawancara dengan Hakim MK I Dewa Gede Palguna, dapat dipastikan bahwa di Indonesia satu-satunya hukum yang bersifat suprematif dalam sistem hukum nasional adalah UUD 1945.

Mengenai kedudukan antara Konstitusi Negara Federal AS, federal statutes, dan perjanjian internasional; konstitusi AS tidak menjelaskan kedudukan antara ketiganya. Case law di AS menjawab permasalahan tersebut. Putusan Mahkamah Agung AS dalam kasus Whitney vs Robertson 1888 yang menjawab status hierarki antara Konstitusi AS, Federal Statutes, dan Perjanjian Internasional. ${ }^{22}$ Setidaknya Putusan atas kasus Whitney v. Robertson 1888 menjawab 2 hal: Pertama, kedudukan hukum Federal Statutes dengan Perjanjian Internasional adalah sejajar, namun keduanya berada satu derajat di bawah Konstitusi; dan Kedua, bilamana federal statues bertabrakan dengan perjanjian internasional maka yang akan berlaku adalah yang diterbitkan paling akhir. ${ }^{23}$

Dalam konteks Indonesia, setidaknya MK telah membuat satu keputusan yang konsisten bilamana berkaitan dengan supremasi konstitusi. UUD 1945 suprematif, dan bahkan bila suatu konvensi internasional bertentangan dengan UUD 1945, maka yang diikuti adalah UUD $1945 .{ }^{24}$ Yang selanjutnya dapat dijawab MK adalah posisi perjanjian internasional dengan sumber-sumber hukum lainnya, sebagaimana Putusan Mahkamah Agung AS pada Kasus Whitney v. Ferguson 1888.

22 Perlu diingat bahwa putusan ini merupakan perkembangan dari prinsip Charming Betsy dari Putusan Mahkamah Agung AS pada Kasus Murray vs. Schooner Betsy 1804. Prinsip ini menjawab bahwa kedudukan federal statutes sejajar dengan hukum kebiasaan internasional, dan penyusun federal statutes harus dapat menyusun statutes yang dapat berkesinambungan dengan hukum kebiasaan internasional.

23 John Quigley, "Toward More Effective Judicial Implementation of Treaty Based-Right", Fordham International Law Journal, Vol. 29, Issue 3, 2005, hlm. 585.

24 Lihat penjeasan terkait putusan-putusan MK di paragraf-paragraf sebelumnya. 
Meskipun sistem hukum Indonesia tidak menerapkan sistem preseden atau case law, tetapi perihal terkait supremasi konstitusi terhadap hukum internasional telah menjadi suatu yurisprudensi tetap dan dapat menjadi sumber hukum formil yang dapat berlaku. ${ }^{25}$

\section{Perjanjian Internasional diterapkan sebagai Sumber Hukum Materiil di Mahkamah Konstitusi}

Mahkamah Konstitusi kerap kali merujuk kepada konvensi-konvensi PBB maupun perjanjian-perjanjian internasional yang mana Indonesia bukan merupakan Negara-Pihak. Hal ini terjadi pada Putusan MK Nomor 065/PUU-II/2004 ${ }^{26}$ tentang Judicial Review UU Pengadilan HAM (asas retroaktif); Putusan MK Nomor 2-3/PUUV/2007 tentang Judicial Review UU Narkotika (hukuman mati); ${ }^{27}$ dan Putusan MK Nomor 13/PUU-I/2003 tentang Judicial Review UU Terorisme. ${ }^{28}$

Hakim Konstitusi I Dewa Palguna, yang menjabat sebagai Hakim MK pada saat ketiga putusan di atas dikeluarkan, mengemukakan dua pandangan tentang mengapa MK merujuk pada instrumen-instrumen hukum internasional yang mana Indonesia bukan merupakan negara pihak: ${ }^{29}$

a. Perjanjian-perjanjian internasional tersebut oleh MK dirujuk hanya sebagai pembanding guna memperkuat pertimbangan hukum Mahkamah. Perjanjianperjanjian internasional tersebut tidak dirujuk sebagai dasar hukum yang mengikat;

b. Di dalam perjanjian-perjanjian internasional, terutama Kovenan-Kovenan PBB, terdapat nilai-nilai moral yang tidak dapat dikesampingkan.

25 Lihat Ernst Utrecht, Pengantar Dalam Hukum Indonesia, cetakan ke-11, Jakarta: P.T Ichtiar Baru dan Sinar Harapan, 1989, hlm. 126. Lebih lanjut Utrecht mengatakan bahwa yurisprudensi tetap terjadi karena suatu rangkaian atau rentetan keputusan-keputusan yang sama sehingga dapat menjadi suatu dasar peradilan (standard-arrest) untuk menyelesaikan suatu masalah yang telah lama melahirkan keragu-raguan.

26 MK pada putusan ini merujuk kepada International Covenant on Civil and Political Rights (ICCPR) yang saat itu Indonesia belum menjadi bagian. MK juga merujuk pada Pasal 7 Konvensi Eropa tentang HAM yang mana Indonesia juga bukan merupakan negara pihak.

27 MK pada putusan ini merujuk pada perjanjian-perjanjian internasional yang mana Indonesia bukan merupakan bagian, yakni: Pasal 76 ayat (3) dan 77 ayat (5) Protocol Additional I to the 1949 Conventions and Relating to the Protection of Victims of International Armed Conflict; Pasal 6 ayat (4) Protocol Additional II to the 1949 Conventions and Relating to the Protection of Victims of International Armed Conflict; Pasal 80 Rome Statute of International Criminal Court; Pasal 2 ayat (2) Convention for the Protection of Human Rights and Fundamental Freedoms (European Convention on Human Rights); dan Pasal 4 American Convention on Human Rights and Fundamental Freedoms Concerning the Abolition of the Death Penalty.

28 MK pada putusan ini merujuk pada beberapa perjanjian internasional yang mana Indonesia bukan merupakan negara pihak, yakni: Pasal 7 European Convention for the Protection of Human Rights and Fundamental Freedoms and Its Eight Protocols, Pasal 4 dan Pasal 15 United Nations International Covenant on Civil and Political Rights 1966, Pasal 9 American Convention on Human Rights, Pasal 22-24 Rome Statute of the International Criminal Court 1998.

29 Wawancara I Dewa Gede Palguna, 27 Juli 2016, di Kantor Mahkamah Konstitusi RI. 
Pada Putusan MK Nomor 65/PUU-II/2004, rujukan MK kepada perjanjianperjanjian internasional dijabarkan oleh MK dalam rangka menjawab mengenai penerapan asas retroaktif di Indonesia sejalan dengan semangat hukum internasional. MK merujuk kepada norma-norma perjanjian internasional terkait HAM untuk memperkuat pendapatnya bahwa UUD 1945 sejalan dengan semangat HAM, bukan justru melanggar HAM. ${ }^{30}$ Rujukan MK dalam putusan ini yang merujuk kepada instrumen-instrumen hukum trans-regional juga dapat diartikan bahwa MK ingin menunjukan bahwa asas retro-aktif masih berlaku di belahan-belahan dunia lain. Dengan kata lain, MK memang merujuk pada perjanjian-perjanjian internasional tersebut sebagai pembanding untuk memperkuat pertimbangan hukum.

Argumen di atas juga berlaku pada Putusan MK Nomor 2-3/PUU-V/2007 tentang Judicial Review UU Narkotika (hukuman mati) dan Putusan MK Nomor 13/PUU-I/2003 tentang Judicial Review UU Terorisme. Pada Putusan MK Nomor 23/PUU-V/2007, MK merujuk kepada instrumen-instrumen hukum internasional yang mana Indonesia bukan Negara-Pihak untuk membandingkan dan membuktikan bahwa hukuman mati masih berlaku dalam hukum internasional dan juga pada masyarakat regional, sehingga MK dapat menjawab bahwa adanya hukuman mati dalam UU Narkotika masih memiliki ruang dalam hukum internasional. Putusan MK Nomor 13/PUU-I/2003 pun sama, MK merujuk kepada 5 perjanjian internasional (2 diantaranya perjanjian regional) sebagai pembanding dan memperkuat pertimbangan hukum terkait asas retroaktif.

Kesyahihan dari praktik MK dalam merujuk instrumen hukum internasional sebagai pembanding dan penguat pertimbangan hukumnya dapat kita temukan pada Putusan MK Nomor 1/PUU-VIII/2010 tentang Judicial Review UU Pengadilan Anak. Mahkamah menyatakan: ${ }^{31}$

"Mahkamah berpendapat bahwa konvensi internasional, rekomendasi Hak-Hak Anak PBB, dan instrumen hukum internasional lainnya batas umur 12 tahun dapat dijadikan perbandingan dalam menentukan batas usia minimal bagi anak dalam pertanggungjawaban hukum. Namun, Mahkamah berpendapat bahwa instrumen hukum internasional dan rekomendasi PBB tidak dapat dijadikan batu uji an sich dalam menilai konstitusionalitas batas usia pertanggungjawaban hukum anak."

Lihat Putusan Mahkamah Konstitusi Nomor 065/PUU-II/2004, Op.cit., hlm. 34. Mahkamah menyatakan, "...semangat yang terkandung dalam UUD 1945 sejalan dengan semangat dalam sejumlah instrumen hukum internasional maupun regional."

31 Putusan MK Nomor 1/PUU-VIII/2010, Op.cit., hlm. 151. 
Dengan kata lain, pendapat mahkamah tersebut setidaknya menegaskan dua hal. Pertama, MK memang mengakui akan praktiknya selama ini dalam menggunakan perjanjian internasional sebagai pembanding dan penguat pertimbangan hukum. Kedua, MK secara implisit menyatakan bahwa instrumeninstrumen hukum internasional tidak dapat menentukan perihal konstitusional (baca: supremasi UUD 1945). Pendapat MK lain yang dapat dijadikan argumen tambahan dalam hal ini ada pada pernyataan MK pada Putusan MK Nomor 23/PUU-V/2007 yang berbunyi:32

"Bahwa diadopsinya Hak-Hak Asasi Manusia dalam UUD 1945 sebagai hukum tertinggi (basic norm), memiliki konsekuensi tersendiri, yaitu Hak Asasi manusia tersebut ikut serta menjadi tolak ukur dalam menilai konstitusionalitas undang-undang yang mempengaruhi dan menyangkut harkat dan martabat manusia yang berada diwilayah hukum negara, in casu Republik Indonesia. Sehingga oleh karenanya hak konstitusional yang diartikan dalam pasal 51 ayat (1) UU MK meliputi juga hak fundamental atau hak asasi manusia yang tidak sematamata memiliki daya laku nasional, melainkan juga universal."

Praktik ini dapat dikaitkan dengan perkembangan hukum internasional itu sendiri. Berkembangnya hukum internasional secara intrusif kedalam kehidupan tiap individu telah mengembangkan prinsip-prinsip universal tentang kemanusiaan yang tidak hanya dapat dianut negara-negara tapi juga dianut oleh masyarakat dunia. Hal ini menurut I Dewa Gede Palguna menjadikan MK tidak dapat begitu saja mengenyampingkan prinsip-prinsip hukum internasional yang berkembang, karena UUD 1945 sendiri memberikan penghargaan yang tinggi kepada perkembangan dunia dan kemanusiaan. ${ }^{33}$ Bagir Manan mengemukakan hal senada, bahwa ada suatu ikatan moral yang mengikat Indonesia sebagai anggota PBB, sehingga kovenan-kovenan PBB yang meskipun Indonesia bukan Negara Pihak, wajib diperhatikan oleh Indonesia. ${ }^{34}$ Argumen tersebut menjadi landasan yang kuat dari praktik ini.

Penerapan perjanjian internasional sebagai pembanding yang tidak mengikat, serta alasan-alasan MK merujuk kepada perjanjian internasional dengan adanya keterikatan moral pada putusan-putusan yang dijelaskan di atas, menunjukan bahwa MK menjadikan perjanjian internasional sebagai sumber hukum materiil. Artinya, perjanjian internasional dengan adanya keterikatan moral tersebut, turut berperan dalam membentuk hukum, yang mana dalam hal ini adalah putusanputusan MK. Sebagai sumber hukum materiil, maka tidak memerlukan suatu

32 Putusan Mahkamah Konstitusi Nomor 2-3/PUU-V/2007, Op.cit., hlm. 446.

33 Wawancara dengan Hakim Konstitusi I Dewa Gede Palguna, 27 Juli 2016.

34 Wawancara dengan Bagir Manan, 28 Juli 2016. 
bentuk hukum tertentu.

Praktik ini juga cenderung mengarah kepada aliran monisme. Meskipun MK memandang perjanjian-perjanjian internasional tersebut tidak dijadikan dasar yang mengikat, akan tetapi praktik ini sesuai dengan konsep-konsep dasar monisme. Alasannya, perjanjian-perjanjian internasional yang belum memiliki status hukum domestik tersebut digunakan dalam pengadilan nasional, terlepas dari apapun pandangan MK. Kentalnya penerapan konsep ini diperkuat ketika MK melakukan penafsiran sistematis pada Putusan MK Nomor 2-3/PUU-V/2007, yang mana Vienna Convention on the Law of Treaties (dalam kapasitasnya sebagai hukum kebiasaan internasional) digunakan sebagai pisau analisis antara norma dalam ICCPR dengan United Nations Convention Against Illicit Traffic in Narcotic Drugs and Psychotropic Substances 1998. Perihal yang terakhir ini akan dibahas pada poin selanjutnya.

\section{Perjanjian Internasional sebagai Sumber Hukum Formil di Mahkamah Konstitusi}

Bila pada putusan-putusan yang dianalisis pada sub-bab di atas perjanjian internasional dirujuk sebagai sumber hukum materiil, maka 2 putusan MK yang akan dibahas pada sub-bab ini mengindikasikan bahwa MK mengklasifikasian perjanjian internasional sebagai sumber hukum formil. Dalam konteks sumber hukum, sumber hukum formil ditaati oleh karena bentuk hukumnya. Artinya, sumber hukum formil memerlukan suatu bentuk hukum tertentu dalam sebuah klasifikasi/hierarki sistem hukum. Putusan MK Nomor 33/PUU-IX/2011 tentang Judicial Review UU Pengesahan ASEAN CHARTER dan Putusan MK Nomor 2-3/PUUV/2007 tentang Judicial Review UU Narkotika mengindikasikan hal tersebut.

Putusan MK Nomor 33/PUU-IX/2011 tentang Judicial Review UU Pengesahan ASEAN CHARTER, MK menyatakan bahwa memiliki kewenangan untuk menguji ASEAN Charter. Putusan MK ini menyiratkan tiga hal, yakni: Pertama, UU ratifikasi dan perjanjian internasional sebagai lampirannya adalah satu kesatuan; Kedua, karena ia adalah undang-undang maka MK dapat mengujinya; Ketiga, MK mengatakan bahwa bentuk UU ini memiliki logical fallacies dan harus ditinjau kembali. ${ }^{35}$ MK juga sudah melakukan penafsiran terhadap Pasal 11 UUD 1945. MK menyatakan bahwa bentuk 'persetujuan DPR' yang dimaksudkan pada Pasal 11 UUD 1945 adalah 'persetujuan internal/parliemantary approval' agar eksekutif dapat meratifikasi suatu perjanjian internasional (consent to be bound). Selanjutnya MK menyatakan bahwa bentuk 'persetujuan DPR' tersebut tidak harus 
berbentuk undang-undang, meskipun produk hukum yang dibuat oleh DPR bersama Presiden adalah undang-undang. Sayangnya, MK tidak menjawab bentuk hukum seperti apa yang tepat digunakan untuk perjanjian internasional berdasarkan UUD 1945. MK juga tidak menjawab bagaimana nanti kedudukan hukum perjanjian internasional bila praktik penerapan perjanjian internasional selama ini diperbaharui. Terlepas dari penafsiran yang belum selesai tersebut, MK menyatakan bahwa pilihan bentuk hukum ratifikasi perjanjian internasional dalam bentuk formil Undang-Undang harus ditinjau kembali. ${ }^{36}$ Namun, perlu diingat adalah sejauh ini MK tetap menganggap bahwa perjanjian internasional yang berlaku adalah Undang-Undang.

Pada Putusan MK Nomor 2-3/PUU-V/2007, ${ }^{37}$ MK menggunakan metode penafsiran dengan menggunakan Pasal 31 VCLT 1969 sebagai dasar dari metode tersebut. ${ }^{38}$ Mahkamah menafsirkan Konvensi Narkotika dan Psikotropika agar memberi penjelasan bahwa kejahatan narkotika dapat digolongkan sebagai serious crimes yang dapat dimasukan ke dalam kategori dari Pasal 6 ayat (2). Pasal 6 ayat (2) ICCPR menyatakan bahwa hukuman mati hanya dapat diterapkan kepada kejahatan yang tergolong most serious crimes. Dengan menafsirkan hal tersebut, Mahkamah menyatakan bahwa kejahatan Narkotika dapat dikategorikan dalam Pasal 6 ICCPR sehingga dapat dikecualikan dalam hal penerapan hukuman mati.

Tidak hanya merujuk kepada Pasal 31 VCLT 1969, MK juga merujuk kepada Pasal 27 dan 46 VCLT 1969 mengenai perihal tidak boleh adanya peraturan perundangundangan nasional menjadi halangan dari penerapan perjanjian internasional yang telah diratifikasi. ${ }^{39}$ MK merujuk kepada pasal-pasal tersebut dalam rangka menjelaskan bahwa keterikatan Indonesia pada ICCPR karena telah meratifikasi kovenan tersebut harus mengingat pula VCLT 1969 sebagai dasar dari rezim hukum perjanjian internasional.

Pada konsep dualisme, perjanjian internasional ditransformasi menjadi peraturan perundang-undangan nasional sehingga kehilangan sifat internasional. Perjanjian internasional tersebut tidak lagi governed by international law, dalam hal ini international law of treaties, namun tunduk pada hukum nasional yang

36 Putusan Mahkamah Konstitusi Nomor 33/PUU-IX/2011, Op.cit., hlm. 195-196.

37 Putusan Mahkamah Konstitusi Nomor 2-3/PUU-V/2007, Op.cit.

$38 \mathrm{Ibid}, \mathrm{hlm}$. 425. Bunyi Pasal 31 Vienna Convention of the Law of Treaties 1969 (VCLT 1969) adalah sebagai berikut: "Suatu perjanjian internasional harus ditafsirkan dengan itikad baik sesuai dengan pengertian sehari-hari yang diberikan terhadap istilah-istilah dalam suatu perjanjian internasional sesuai dengan konteksnya dan dengan mengingat objek dan tujuan perjanjian internasional tersebut."

39 Ibid, hlm. 420. MK mengawali pembahasan tentang rujukannya kepada VCLT 1969 dengan menyatakan: "untuk mengetahui ada-tidaknya pelanggaran suatu kewajiban internasional yang lahir dari perjanjian internasional, ketentuan yang harus dijadikan rujukan pertama adalah ketentuan-ketentuan yang tertuang dalam Konvensi Wina Tahun 1969 tentang Perjanjian Internasional (Vienna Convention on the Law of Treaties 1969, selanjutnya disebut Konvensi Wina 1969), yang khusus berlaku bagi perjanjian internasional negara dengan negara". 
mengatur mengenai peraturan perundang-undangan nasional. ${ }^{40}$ Karena di Indonesia yang berlaku adalah perjanjian internasional sama dengan undangundang, maka seharusnya perjanjian internasional yang sudah diratifikasi tidak lagi tunduk pada rezim international law of treaties. Berkaitan dengan Putusan MK Nomor 2-3/PUU-V/2007, ICCPR dan Konvensi Narkotika dan Psikotropika telah diratifikasi dan masing-masing memiliki undang-undang ratifikasi, sehingga kapasitasnya seharusnya adalah sebagai undang-undang.

Indonesia bukan merupakan Negara-Pihak dari VCLT 1969, namun VCLT telah diakui sebagai bagian dari hukum kebiasaan internasional. ${ }^{41}$ Dalam metodologi hukum internasional, negara terikat kepada hukum kebiasaan internasional kecuali negara dimaksud melakukan penolakan secara konsisten. ${ }^{42}$ Meski selama ini perjanjian internasional dianggap sebagai undang-undang, Putusan MK Nomor 23/PUU-V/2007 menunjukan indikasi bahwa perjanjian internasional di Indonesia masih memiliki sifat internasional, yakni governed by international law. Indikasi ini dapat ditarik dari praktik MK pada putusan tersebut dengan menggunakan Pasal 31 VCLT 1969 sebagai dasar interpretasi ICCPR dan Konvensi Narkotika dan Psikotropia dan Pasal 27 dan 46 sebagai norma yang tidak boleh dilanggar. Hal ini mengartikan dua hal, yaitu:

a. Perjanjian internasional, meski bentuknya adalah lampiran dalam undangundang ratifikasi, masih memiliki sifat governed by international law. Ini dikarenakan MK menggunakan VCLT 1969 sebagai hukum kebiasaan internasional dalam pertimbangan hukumnya. Padahal, Indonesia memiliki Undang-Undang Nomor 24 Tahun 2000 tentang Perjanjian Internasional (UU Perjanjian Internasional), namun sama sekali tidak dirujuk oleh MK.

b. Bila memandang ICCPR dan Konvensi Narkotika dan Psikotropika sebagai undang-undang, maka muncul pertanyaan mengenai kedudukannya bila disandingkan dengan hukum kebiasaan internasional. MK dalam pertimbangannya menyatakan bahwa penegakan perjanjian internasional tidak boleh terhambat oleh hukum nasional sebagaimana diatur oleh VCLT 1969. Artinya, pada kasus ini, MK menyatakan secara tidak langsung menjadikan VCLT 1969 (sebagai hukum kebiasaan internasional berada di atas) sebagai kaidah hukum yang lebih tinggi dari ICCPR dan Konvensi Narkotika dan Psikotropika (sebagai undang-undang).

40 Lihat G.C. Thornton, Legislative Drafting, London: Butterworths, 1987, hlm. 236; Lambertus Erades dan Wesley Gould, The Relation between International Law and Municipal Law in the Netherlands and in the United States, Leiden: A.W. Sythoff, 1961, hlm. 297; Peter van Dijk dan Bahiyyih Tahzib, "Parliemantary Participation in the Treaty Making Process of the Netherlands", Chicago-Kent Law review, Vol. 67, 1991, hlm. 417-418.

41 Anthony Aust, Vienna Convention on the Law of Treaties (1969), Oxford: Oxford Public International Law, 2006, http://opil.ouplaw.com/view/10.1093/law:epil/9780199231690/law-9780199231690-e1498.

42 Damos Dumoli Agusman, Hukum Perjanjian Internasional: Kajian Teori dan Praktik, Bandung: PT. Refika Aditama, 2010, hlm. 138. 
Hal selanjutnya yang penting menjadi catatan adalah, MK mengatakan dalam Putusan MK Nomor 33/PUU-IX/2011 bahwa keikutsertaan Indonesia dalam ASEAN Charter dapat berakhir sesuai dengan ketentuan Pasal 18 huruf (h) UU Perjanjian Internasional. Pendapat MK ini mengindikasikan bahwa perjanjian internasional yang berlaku di Indonesia tunduk pada hukum nasional Indonesia tentang perjanjian internasional. Di satu sisi, pada Putusan MK Nomor 2-3/PUU-V/2007 MK merujuk keterikatan perjanjian internasional yang mana RI merupakan NegaraPihak pada VCLT 1969 sehingga mengindikasikan bahwa perjanjian internasional tersebut masih memiliki karakter internasional (governed by international law). Dalam hal kedudukan hukum, MK juga meninggalkan kebingungan bagaimana kedudukan antara perjanjian internasional, undang-undang, serta hukum kebiasaan internasional.

\section{Penerapan Perjanjian Internasional di Pengadilan Nasional Indonesia di Masa Depan}

Penerapan perjanjian internasional di Indonesia selama ini di Mahkamah Konstiusi belum dapat menjawab beberapa pertanyaan. Satu-satunya jawaban yang dapat dipastikan hanya mengenai supremasi UUD 1945 di atas kaidah-kaidah hukum lain, termasuk diantaranya hukum internasional. Namun, pertanyaan terkait bentuk hukum domestik perjanjian internasional serta kedudukannya belum dapat dijawab oleh Mahkamah Konstitusi. Di satu sisi, praktik Mahkamah Konstitusi selama ini mengindikasikan bahwa perjanjian internasional memiliki fungsi yang kuat sebagai sumber hukum di Indonesia. Norma-norma hukum internasional terutama mengenai HAM seringkali dirujuk oleh MK karena MK menganggap bahwa ada satu keterikatan moral antara Negara Indonesia dengan hukum internasional. Meski selama ini perjanjian internasional berlaku dalam bentuk UU, UU Perjanjian Internasional itu sendiri diperlakukan lebih istimewa.

Inkonsistensi penerapan perjanjian internasional di Pengadilan Nasional Indonesia, baik di level MK maupun peradilan umum, ${ }^{43}$ tidak lepas dari minimnya konstruksi hukum yang mengatur tentang hubungan hukum internasional dengan hukum nasional. Ketentuan konstitusional dalam UUD 1945 sendiri masih terlalu sederhana. Sepanjang perkembangannya sejak tahun 1945 hingga sekarang, hanya Pasal 11 yang menjadi materi muatan terkait perjanjian internasional dan hanya mengalami perubahan terkait 'persetujuan DPR'. Terlalu sederhananya ketentuan konstitusional ini menimbulkan banyak permasalahan hukum di bidang praktis. Terutama frasa 'persetujuan DPR' yang menimbulkan polemik, seakan DPR ikut dalam semua tahapan pembuatan perjanjian internasional serta menyamakan 
perjanjian internasional dengan Undang-Undang di dalam sistem hukum nasional. ${ }^{44}$ Ditambah lagi dengan perkembangan yang masih stagnan ini, maka akan muncul kemungkinan-kemungkinan perjanjian internasional diuji-materi dan dibatalkan MK dan dapat berakibat Indonesia melanggar hukum internasional.

Amerika Serikat dan Belanda menyediakan ketentuan konstitusional yang lebih lengkap terkait isu ini. Adanya supremacy clause dalam materi muatan konstitusi mereka meredam hampir seluruh isu terkait pertentangan hukum internasional dan hukum nasional. Pasal 91 Konstitusi Belanda dengan jelas menyatakan bahwa seluruh ketentuan hukum nasional akan menjadi tidak berlaku ketika bertentangan dengan norma perjanjian internasional yang mengikat negara Belanda. ${ }^{45}$ Bahkan, Konstitusi Belanda memungkinkan negara untuk ikut serta dalam perjanjian internasional yang bertentangan dengan Konstitusi itu sendiri. ${ }^{46}$

Terkait dengan bentuk persetujuan parlemen terhadap perjanjian internasional, Konstitusi Belanda menyebutkan dengan eksplisit bahwa persetujuan yang dimaksud merupakan persetujuan internal parlemen, serta dapat berbentuk tacit approval. ${ }^{47}$ Sedangkan di Amerika Serikat, case law yang berkembang juga telah menjawab berbagai pertanyaan-pertanyaan terkait supreme clause yang di kandung Konstitusi AS. Terkait kedudukan, perjanjian internasional hanya satu derajat di bawah Konstitusi serta sederajat dengan Federal Statutes ${ }^{48}$ Terkait bentuk domestik dari perjanjian internasional, perkembangan case law AS menegaskan bahwa sepanjang suatu ketentuan perjanjian internasional bukan merupakan non-self executing, maka perjanjian internasional itu berlaku dan diterapkan di pengadilan sebagai perjanjian internasional (bukan peraturan perundang-undangan nasional). ${ }^{49}$

Putusan pengadilan telah memiliki peran yang begitu besar pada perkembangan hukum perjanjian internasional di AS dan Belanda. Belanda mesti tidak menerapkan sistem hukum preseden, tetap mendapatkan pengaruh putusanputusan pengadilan dalam perkembangannya. Sebelum adanya Pasal 92 (2) hasil amandemen Konstitusi Belanda 1953, Konstitusi AS hanya mengakomodir 'persetujuan parlemen' dalam bentuk formil berupa goedkerungswet. Goedskerungswet juga menimbulkan perdebatan perihal legislative character

44 Ibid, hlm. 475.

45 Pasal 94 Konstitusi Kerajaan Belanda.

46 Pasal 91 (3) Konstitusi Kerajaan Belanda. Ini dimungkinkan bila 2/3 dari House of States Generals menyetujuinya.

47 Pasal 91 (2) Konstitusi Kerajaan Belanda.

48 Lihat Pasal VI Konstitusi AS; Putusan Mahkamah Agung AS pada Kasus Murray v. Schooner Charming Betsy 1804; dan Putusan Mahkamah Agung AS pada Kasus Whitney v. Robertson 1888.

49 Lihat Putusan Mahkamah Agung AS pada Kasus Foster v. Neilsen 1829; dan Putusan Mahkamah Agung AS pada Kasus Meddelin v. Texas 2004. 
dalam sumber hukum, sama seperti di Indonesia akhir-akhir ini. Lahirnya Pasal 92 (2) dilatar belakangi oleh perkembangan case law. ${ }^{50}$

Berhubung semakin intrusifnya hukum internasional berkembang ke dalam lingkup nasional, Indonesia harus segera menentukan posisinya dalam menempatkan hukum internasional. Inkonsistensi dalam penerapan perjanjian internasional di pengadilan selama ini dapat menyebabkan Indonesia gagal menegakan atau bahkan melanggar hukum internasional. Praktik MK selama ini dalam menerapkan perjanjian internasional, sebagian besar dikarenakan, menurut MK, adanya keterikatan moral. Tentu dengan melihat Konstitusi AS dan Belanda, dorongan untuk melakukan amandemen UUD 1945 bermunculan.

Namun amandemen konstitusi memerlukan upaya politik yang membutuhkan waktu dan tenaga yang cukup banyak. Sementara itu globalisasi menuntut segala hal siap dalam tempo yang singkat. Alternatif yang dapat menjadi solusi selain dari amandemen konstitusi lewat MPR adalah melalui judicial interpretation oleh MK. ${ }^{51}$ MK sebagai lembaga yang memiliki peran besar dalam menjaga UUD 1945 sebagai the living constitution berwenang untuk menciptakan kaidah konstitusi baru tanpa merubah teks konstitusi asli. ${ }^{52}$

Menurut Bagir Manan, yurisprudensi ketatanegaraan sebagai salah satu sumber hukum tata negara dapat melahirkan dan mematikan kaidah-kaidah hukum tata negara. ${ }^{53}$ Mahkamah Konstitusi berperan besar dalam melahirkan dan mematikan kaidah hukum ketatanegaraan, termasuk diantaranya wewenang ketatanegaraan dan hubungan antar alat kelengkapan negara. ${ }^{54}$ Artinya, Mahkamah Konstitusi adalah lembaga yang dapat menjawab kebuntuan dari permasalahan status hukum perjanjian internasional di dalam sistem hukum nasional. Meski Indonesia adalah negara yang tidak menerapkan sistem preseden, akan tetapi putusan pengadilan tetap bersifat final \& binding yang dapat memiliki kekuatan memaksa agar pengadilan selanjutnya mengikuti atau setidaknya memerhatikan yurisprudensi tersebut.

Hingga hari ini MK belum mendapatkan ujian nyata yang mengharuskan MK menguji terkait adanya norma hukum nasional yang bertentangan dengan norma perjanjian internasional. ${ }^{55}$ Jika suatu saat MK harus menguji hal tersebut, maka berdasarkan penelitian ini MK memiliki beberapa opsi:

\footnotetext{
50 Lihat Damos Dumoli Agusman, Treaties under Indonesian Law, Op.cit, hlm. 341-346; dan Lambertus Erades dan Wesley Gould, Op.cit., hlm. 307-335.

Wawancara dengan Hakim Konstitusi I Dewa Gede Palguna, 27 Juli 2016.

52 Bagir Manan, Memahami Konstitusi: Makna dan Aktualisasi, Jakarta: Rajawali Press, 2014, hlm. 151-152.

53 Bagir Manan, Konvensi Ketatanegaraan, Yogyakarta: FH UII Press, 2006, hlm. 39-40.

54 lbid.

55 Damos Dumoli Agusman, Treaties under Indonesian Law, Op.cit., hlm. 414.
} 
1. Meski beberapa pertanyaan seputar isu ini belum dapat dijawab oleh MK, satu hal yang pasti dan selalu ditegaskan secara konsisten oleh MK adalah mengenai supremasi UUD 1945 sebagai kaidah tertinggi.

Belanda menaruh penghargaan yang amat tinggi kepada perjanjian internasional, karena memiliki sejarah ketatanegaraan yang berhubungan dengan perjanjian internasional secara intim. Bagi Belanda, negara mereka lahir karena perjanjian internasional. ${ }^{56}$ Oleh karena itu hingga hari ini konstitusi dapat dikalahkan oleh perjanjian internasional. ${ }^{57}$ Sejarah ketatanegaraan, merupakan bagian dari sumber hukum ketatanegaraan materiil. ${ }^{58}$

MK selanjutnya dapat menjabarkan kesyahihan dari supremasi UUD 1945 dalam sistem hukum berdasarkan sumber hukum ketatanegaraan materiil. Hal ini bertujuan agar perihal UUD 1945 ada di atas perjanjian internasional dapat terjawab.

2. Bila poin nomor 1 di atas terjawab bahwa UUD 1945 secara sumber hukum ketatanegaraan materiil memang bersifat suprematif, maka setidak-tidaknya doktrin, dogma, dan praktik MK selama ini perihal supremasi UUD 1945 dapat dibenarkan. Yang perlu selanjutnya dijawab adalah perihal bentuk, fungsi, dan kedudukan domestik perjanjian internasional.

3. Bila poin nomor 1 di atas terjawab sebaliknya, bahwa Indonesia berdasarkan sumber hukum ketatanegaraan materiil adalah monisme primat hukum internasional, maka struktur hukum di Indonesia akan memerlukan perubahan yang cukup masif. Contoh yang paling sering dikutip oleh ahli hukum Indonesia terhadap pandangan ini adalah kutipan Pidato Wakil Presiden Mohammad Hatta (saat itu menjabat Perdana Menteri RIS) tanggal 11 Agustus 1950 yang berbunyi, "Berdasarkan anggapan-anggapan yang diterima dalam pergaulan antara negara-negara, maka traktat itu lebih tinggi dari pada undang-undang dasar." 59

4. Bila poin 1 telah sesuai dengan poin 2 , maka permasalahan selanjutnya adalah menempatkan posisi antara UU dengan perjanjian internasional. Ada 2 pilihan turunan terkait hal ini:

a. Perjanjian internasional berada satu derajat lebih tinggi dari undang-undang nasional. Dengan Argumenasi bahwa Indonesia memiliki penghargaan yang tinggi terhadap perkembangan nilai kemanusiaan dan dunia, yang didasari

56 Belanda telah 200 tahun memegang teguh prinsip ini dengan landasan bahwa Kerajaan Belanda lahir dari perjanjian internasional, yakni Treaty of Vienna 1815. Lihat Gregory Fermont-Barnes, Encyclopedia of the Age of Political Revolutions and New Ideologies, 1760-1815, Greenwood Press: Michigan, 2007, hlm. 509.

57 Lihat Pasal 91 (2) Konstitusi Belanda.

58 Lihat Bagir Manan, Konvensi Ketatanegaraan, Op.cit., hlm. 35.

59 Ernst Utrecht, Pengantar Dalam Hukum Indonesia, Op.cit., hlm. 458. 
oleh Pembukaan UUD 1945. Hal ini telah didukung lewat praktik MK selama ini, terutama mengenai perkara HAM, yang selalu mempertimbangkan instrumen-instrumen hukum internasional. Bahkan seringkali MK merujuk kepada instrumen hukum internasional yang mana Indonesia bukan NegaraPihak.

b. Perjanjian internasional berada sederajat dengan undang-undang nasional, dengan tetap mempertahankan karakternya sebagai instrumen hukum internasional seperti yang diterapkan di Amerika Serikat. ${ }^{60}$ Karena karakternya sebagai perjanjian internasional, ia tidak dapat diuji di MK, terkecuali ia adalah UU impelementasi dari non self-executing treaties. Bilamana ia bertentangan dengan undang-undang nasional, maka yang berlaku adalah yang paling akhir diterbitkan. Adapun bentuk approval dari DPR tidak lagi harus berbentuk UU.

5. Dua pilihan lain yang tidak direkomendasikan berdasarkan tulisan ini adalah:

a. Menyamakan Undang-Undang dengan perjanjian internasional tanpa ada perbedaan. Permasalahan dari poin ini adalah dapat dimungkinkan terjadi logical fallacies seperti yang diuraikan oleh MK dalam Putusan MK Nomor 33/PUU-IX/2011 tentang Judicial Review UU Pengesahan ASEAN CHARTER, kemungkinan adanya norma perjanjian internasional diuji materilkan ke MK, dan bertentangan dengan norma hukum nasional.

b. Menempatkan perjanjian internasional di bawah derajat Undang-Undang Nasional, terkecuali untuk perjanjian internasional yang tidak memiliki dampak luas sebagaimana dijabarkan dalam Pasal 10 UU Perjanjian Internasional. Dengan mengambil pilihan ini norma perjanjian internasional akan jauh lebih mudah diubah atau dibatalkan.

\section{Penutup}

Konflik yang timbul dari hubungan hukum internasional dan hukum nasional, bergantung pada hukum konstitusi suatu negara. ${ }^{61}$ Dalam konteks Indonesia, diamnya UUD 1945 dalam hal fungsi perjanjian internasional dalam sistem hukum nasional menjadi latar belakang utama dari inkonsistensi MK dalam menerapkan perjanjian international. Hal ini berbanding terbalik dengan supremacy clause yang ada pada Konstitusi Amerika Serikat dan Konstitusi Belanda, yang secara jelas menepatkan perjanjian internasional dalam sistem hukum nasionalnya. Di lain pihak, seharusnya Mahkamah Konstitusi dapat menjawab kebuntuan dari 
penerapan perjanjian internasional di pengadilan nasional Indonesia, oleh karena MK adalah penafsir utama Konstitusi.

Putusan-putusan MK selama ini mengindikasikan bahwa sejauh terkait perjanjian internasional sebagai sumber hukum di Indonesia, MK tidak konsisten dalam menerapkan perjanjian internasional sebagai sumber hukum materiil ataupun formil. Inkonsistensi ini semakin membingungkan terkait pendekatan Indonesia terhadap hukum internasional, bahkan memiliki resiko Indonesia dapat melanggar hukum internasional. Di masa depan, entah lewat penafsiran MK ataupun lewat amandemen UUD 1945, perjanjian internasional sebaiknya dijadikan sumber hukum yang berdiri sendiri, terpisah dari Undang-Undang. Dengan begitu maka perjanjian internasional dapat langsung diterapkan di pengadilan dan tidak dapat diuji di Mahkamah Konstitusi.

\section{Daftar Pustaka}

\section{Buku}

Aust, Anthony, Vienna Convention on the Law of Treaties (1969), Oxford: Oxford Public International Law, 2006.

B.G, Ramcharan (eds), Human Rights: Thirty Years After the Universal Declaration, Springer, Netherlands, 1979.

Bagir Manan, Membedah UUD 1945, Universitas Brawijaya Press, Malang, 2012. Memahami Konstitusi: Makna dan Aktualisasi, Rajawali Press, Jakarta, 2014. , Konvensi Ketatanegaraan, FH UII Press, Yogyakarta, 2006.

Damos Dumoli Agusman, Hukum Perjanjian Internasional: Kajian Teori dan Praktik, PT. Refika Aditama, Bandung, 2010.

Treaties Under Indonesian Law: A Comparative Study, PT.

Remaja Rosdakarya, Bandung, 2014.

Erades, Lambertus., dan Wesley Gould, The Relation between International Law and Municipal Law in the Netherlands and in the United States, A.W. Sythoff, Leiden, 1961.

Ernst Utrecht, Pengantar Dalam Hukum Indonesia, PT. Ichtiar Baru dan Sinar Harapan, Jakarta, 1989.

Greig, D.W., International Law, Butterworth \& Co Publishers Ltd; 2nd edition, 1976. Haljan, David, Separating Powers: International Law before National Courts, T.M.C Asser Press, Leuven, 2013.

Fermont-Barnes, Gregory, Encyclopedia of the Age of Political Revolutions and New Ideologies, 1760-1815, Greenwood Press, Michigan, 2007.

Mochtar Kusumaatmadja, Pengantar Hukum Internasional, PT. Alumni, Bandung, 
2003.

Thornton, G.C., Legislative Drafting, Butterworths, London, 1987.

\section{Dokumen Lain}

http://law.cornell.edu/

Quigley, John, "Toward More Effective Judicial Implementation of Treaty BasedRight", Fordham International Law Journal, Volume 29, Issue 3, 2005.

United Nations, "United Nations Treaty Collections", https://treaties.un.org/doc/source/events/2005/list.pdf, diakses pada 29 Maret 2016.

van Dijk, Peter dan Bahiyyih Tahzib, "Parliemantary Participation in the Treaty Making Process of the Netherlands", Chicago-Kent Law Review, Vol. 67, 1991.

Wawancara dengan Bagir Manan, 28 Juli 2016, bertempat di kediaman Bagir Manan.

Wawancara dengan Damos Agusman, 10 Februari 2016, via linimasa Facebook.

Wawancara dengan I Dewa Gede Palguna, 27 Juli 2016, bertempat di Kantor Mahkamah Konstitusi Republik Indonesia.

\section{Dokumen Hukum}

Undang Undang Dasar 1945.

Undang-Undang Nomor 12 Tahun 2011 tentang Pembentukan Peraturan Perundang-undangan.

Undang-Undang Nomor 24 Tahun 2000 tentang Perjanjian Internasional.

Undang-Undang Nomor 48 Tahun 2009 tentang Kekuasaan Kehakiman.

Putusan Mahkamah Konstitusi Nomor 12/PUU-I/2003, putusan diucapkan dalam sidang Pleno Mahkamah Konstitusi yang terbuka untuk umum pada hari Kamis, 28 Oktober 2004.

Putusan Mahkamah Konstitusi Nomor 13/PUU-I/2003, putusan diucapkan dalam sidang Pleno Mahkamah Konstitusi yang terbuka untuk umum pada hari Jumat, 23 Juli 2004.

Putusan Mahkamah Konstitusi Nomor 065/PUU-II/2004, putusan diucapkan dalam sidang Pleno Mahkamah Konstitusi yang terbuka untuk umum pada hari Kamis, 3 Maret 3005.

Putusan Mahkamah Konstitusi Nomor 013-022/PUU-IV/2006, putusan diucapkan dalam sidang Pleno Mahkamah Konstitusi yang terbuka untuk umum pada hari Rabu, 6 Desember 2006.

Putusan Mahkamah Konstitusi Nomor 2-3/PUU-V/2007, putusan diucapkan dalam sidang Pleno Mahkamah Konstitusi yang terbuka untuk umum pada hari Selasa, 30 Oktober 2007. 
Putusan Mahkamah Konstitusi Nomor 140/PUU-VII/2009, putusan diucapkan dalam sidang Pleno Mahkamah Konstitusi yang terbuka untuk umum pada hari Senin, 19 April 2010.

Putusan Mahkamah Konstitusi Nomor 1/PUU-VIII/2010, putusan diucapkan dalam sidang Pleno Mahkamah Konstitusi yang terbuka untuk umum pada hari Rabu, 2 Februari 2011.

Putusan Mahkamah Konstitusi Nomor 5/PUU-VIII/2010, putusan diucapkan dalam sidang Pleno Mahkamah Konstitusi yang terbuka untuk umum pada hari Kamis, 24 Februari 2011.

Putusan Mahkamah Konstitusi Nomor 33/PUU-IX/2011, putusan diucapkan dalam sidang Pleno Mahkamah Konstitusi yang terbuka untuk umum pada hari Senin, 4 Februari 2013.

Putusan Mahkamah Konstitusi Nomor 38/PUU-IX/2011, putusan diucapkan dalam sidang Pleno Mahkamah Konstitusi yang terbuka untuk umum pada hari Senin, 12 Maret 2012.

Konstitusi Kerajaan Belanda.

Konstusi Amerika Serikat.

Protocol Additional I to the 1949 Conventions and Relating to the Protection of Victims of International Armed Conflict.

Protocol Additional II to the 1949 Conventions and Relating to the Protection of Victims of International Armed Conflict.

Convention for the Protection of Human Rights and Fundamental Freedoms 1950.

United Nations International Covenant on Civil and Political Rights 1966.

Vienna Convention on the Law of Treaties 1969.

Rome Statute of International Criminal Court 1998.

American Convention on Human Rights and Fundamental Freedoms Concerning the Abolition of the Death Penalty 1969

Putusan Mahkamah Agung AS pada Kasus Murray v. Schooner Charming Betsy 1804.

Mahkamah Agung AS pada Kasus Foster v. Neilsen 1829.

Putusan Mahkamah Agung AS pada Kasus Whitney v. Robertson 1888.

Putusan Mahkamah Agung AS pada Kasus Meddelin v. Texas 2004. 